\title{
Origin of kamacite, schreibersite, and perryite in metal-sulfide nodules of the enstatite chondrite Sahara 97072 (EH3)
}

\author{
Stephen W. LEHNER ${ }^{1 *}$, Peter R. BUSECK ${ }^{1}$, and William F. McDONOUGH ${ }^{2}$ \\ ${ }^{1}$ Arizona State University, SESE, Tempe, Arizona 85287-1404, USA \\ ${ }^{2}$ Department of Geology, University of Maryland, College Park, Maryland 20742, USA \\ "Corresponding author. E-mail: slehner@asu.edu
}

(Received 02 April 2009; revision accepted 28 November 2009)

\begin{abstract}
Perryite $\left[(\mathrm{Fe}, \mathrm{Ni})_{\mathrm{x}}(\mathrm{Si}, \mathrm{P})_{\mathrm{y}}\right]$, schreibersite $\left[(\mathrm{Fe}, \mathrm{Ni})_{3} \mathrm{P}\right]$, and kamacite $(\alpha \mathrm{FeNi})$ are constituent minerals of the metal-sulfide nodules in the Sahara 97072 (EH3) enstatite chondrite meteorite. We have measured concentrations of $\mathrm{Ni}, \mathrm{Cu}, \mathrm{Ga}, \mathrm{Au}, \mathrm{Ir}, \mathrm{Ru}$, and $\mathrm{Pd}$ in these minerals with laser ablation, inductively coupled plasma mass spectrometry (ICPMS). We also measured their $\mathrm{Fe}, \mathrm{Ni}, \mathrm{P}, \mathrm{Si}$, and $\mathrm{Co}$ concentrations with electron microprobe. In kamacite, ratios of $\mathrm{Ru} / \mathrm{Ir}, \mathrm{Pd} / \mathrm{Ir}$, and $\mathrm{Pd} / \mathrm{Ru}$ cluster around their respective CI values and all elements analyzed plot near the intersection of the equilibrium condensation trajectory versus $\mathrm{Ni}$ and the respective $\mathrm{CI}$ ratios. In schreibersite, the $\mathrm{Pd} / \mathrm{Ru}$ ratio is near the $\mathrm{CI}$ value and perryite contains significant $\mathrm{Cu}, \mathrm{Ga}$, and $\mathrm{Pd}$. We propose that schreibersite and perryite formed separately near the condensation temperatures of $\mathrm{P}$ and $\mathrm{Si}$ in a reduced gas and were incorporated into $\mathrm{Fe}-\mathrm{Ni}$ alloy. Upon further cooling, sulfidation of $\mathrm{Fe}$ in kamacite resulted in the formation of additional perryite at the sulfide interface. Still later, transient heating re-melted this perryite near the Fe-FeS eutectic temperature during partial melting of the metal-sulfide nodules. The metal-sulfide nodules are preaccretionary objects that retain CI ratios of most siderophile elements, although they have experienced transient heating events.
\end{abstract}

\section{INTRODUCTION}

The mineralogy and compositions of enstatite chondrite (EC) meteorites pose questions regarding the nature and homogeneity of the solar nebula where chondrites formed. Unique mineralogy — enstatite with low $\mathrm{FeO}$ content, $\mathrm{Ca}$ and $\mathrm{Mg}$ sulfides, and $\mathrm{Fe}-\mathrm{Ni}$ alloy containing up to $2.5 \mathrm{wt} \% \mathrm{Si}$-indicates ECs formed in a highly reduced environment. Based on bulk chemical analyses, several workers have proposed that ECs formed from a nebular region depleted in refractory elements (Kong et al. 1997; Hutson and Ruzicka 2000; Grossman et al. 2008). The reduced mineral assemblages and refractory element fractionation imply significant chemical differences between the nebular environment where the ECs formed and the formation regions of ordinary and carbonaceous chondrites (Kallemeyn and Wasson 1986; Grossman et al. 2008).

In the most unequilibrated EH3s, a large fraction of opaque phases are incorporated into metal-sulfide nodules, most of which are dominated by kamacite. The spheroidal metal-sulfide nodules in highly unequilibrated EH3s such as Sahara 97072 (Fig. 1) and Qingzhen were proposed to be pre-accretionary nebular objects that experienced condensation/evaporation and transient nebular melting events as well as several later metamorphic episodes (Rambaldi et al. 1986; El Goresy et al. 1988; Kimura 1988; Ikeda 1989; Lin and El Goresy 2002; Weisberg et al. 2006). Schreibersite and perryite were proposed to form by exsolution from $\mathrm{Fe}-$ Ni alloy in EH3s (El Goresy et al. 1988; Kimura 1988; Ikeda 1989) and as condensates (Kallemeyn and Wasson 1986; Lin and El Goresy 2002). To test these hypotheses, we investigated the trace siderophile element distribution in Sahara 97072 in which Ni is distributed among kamacite (average $4 \mathrm{wt} \% \mathrm{Ni}$ ), perryite (average $69 \mathrm{wt} \% \mathrm{Ni}$ ), and schreibersite (average $13 \mathrm{wt} \% \mathrm{Ni}$ ). Distributions of trace siderophile elements, as a result of their varied volatility, diffusivity, and solid/melt compatibility, have the potential to constrain formation 


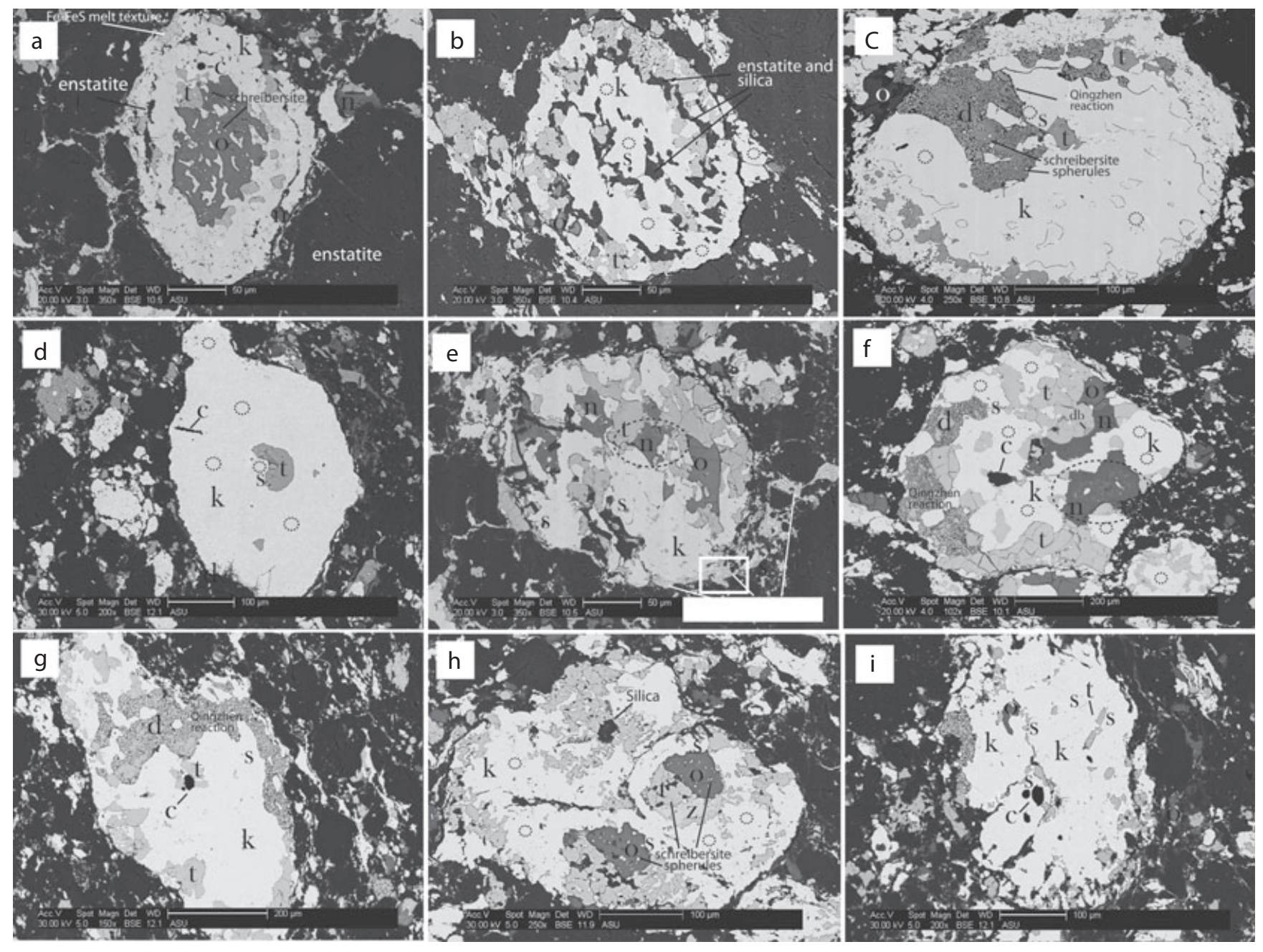

Fig. 1. Backscattered electron images of metal-sulfide nodules in Sahara 97072 displaying a and b) concentric silicate rings; b, c, f, i, g) graphite-schreibersite cores; d) massive kamacite; e and f) oldhamite-niningerite-troilite cores; a and h) oldhamite cores; c, $\mathrm{g}$, f) fine-grained troilite and other sulfides enclosing large grains of djerfisherite; h) a large grain of Fe-rich sphalerite. $\mathrm{c}$ - graphite, $\mathrm{d}$-djerfisherite, $\mathrm{k}$-kamacite, $\mathrm{o}$-oldhamite, $\mathrm{n}$-niningerite, $\mathrm{s}$-schreibersite, $\mathrm{t}$ - troilite, $\mathrm{db}$ - daubreelite, $\mathrm{z}$ - sphalerite. The dashed ovals outline (e) reverse-zoned niningerite, and (f) normal-zoned niningerite. The white rectangle highlights Fe-FeS myrmekitic-eutectic texture which is enlarged in Fig. 3. The small dotted circles represent laser ablation, inductively coupled plasma mass spectrometry (LA-ICPMS) analyses.

processes of their carrier phases and therefore illuminate the thermal history of the metal-sulfide nodules.

Fe-Ni alloy is thought to have condensed from the solar nebula (Grossman 1972; Kelly and Larimer 1977; Grossman and Wasson 1985; Campbell et al. 2001) or, in some meteorites, to have formed by reduction of Ferich silicates and FeS (Zanda et al. 1994; Campbell et al. 2005b). As most siderophile elements are more easily reduced to metal than Fe and are unlikely to have fractionated into silicates (Larimer and Wasson 1988), we assume that cosmic proportions of these elements in a metal imply a condensation origin (Kelly and Larimer 1977) and recognize that later thermal processes may have occurred. Subsequent oxidation or reduction of $\mathrm{Fe}$ in $\mathrm{Fe}-\mathrm{Ni}$ alloy would preserve trace element proportions but shift them parallel to the $\mathrm{CI}$ element/ $\mathrm{Ni}$ trend (Kelly and Larimer 1977). In EH3s, Si and P in the Fe$\mathrm{Ni}$ alloy stabilize perryite and schreibersite as high-Ni phases.

In Sahara 97072, perryite inclusions occur throughout kamacite but are concentrated at the interface of kamacite with troilite and near the edges of the metal-sulfide nodules (Fig. 2). It is possible that some perryite inclusions not appearing to be associated with sulfides actually are when the third dimension of thin sections is considered. The kamacite-perryite-troilite assemblage was interpreted to be a product of sulfidation of Fe-Ni alloy (Rambaldi et al. 1986; Lin 

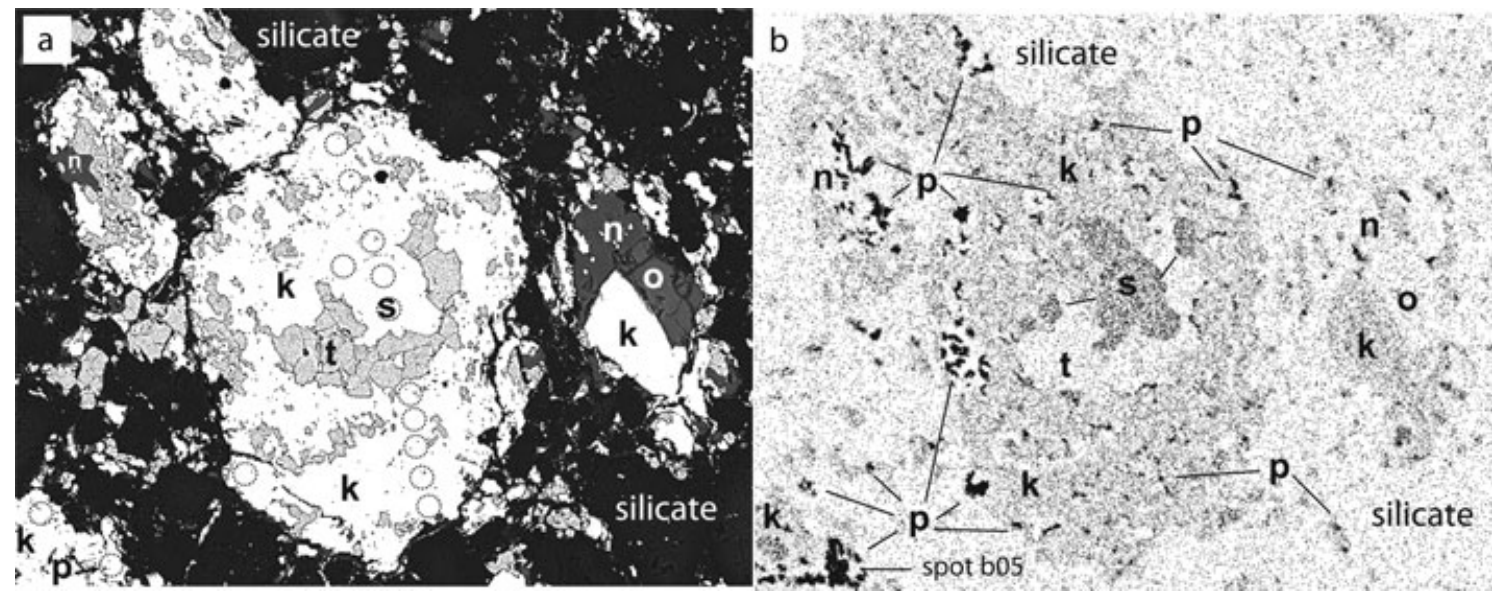

Fig. 2. a) Backscattered electron image of a metal-sulfide nodule. b) Ni K $\alpha$ map of image in (a) showing perryite distribution. Dark areas are perryite. The symbols are the same as in Fig. 1. The dotted circles represent laser ablation, inductively coupled plasma mass spectrometry (LA-ICPMS) analyses.

and El Goresy 2002). The Ni concentration of kamacite plus perryite in the most unequilibrated ECs is in the range of the $\mathrm{Ni}$ concentration in kamacite alone in higher petrologic types, implying that perryite dissolved into kamacite during metamorphism (Easton 1986). Therefore, perryite was proposed as a high-temperature condensate (Kallemeyn and Wasson 1986).

Schreibersite occurs at or near the cores of metalsulfide nodules and as smaller spherules within niningerite, oldhamite, troilite, and other sulfides (Figs. 1a, 1c, and 1h). Schreibersite spherules were proposed to be an earlier condensate than oldhamite in Qingzhen metal-sulfide nodules (Lin and El Goresy 2002), and oldhamite was interpreted as a hightemperature condensate (Larimer and Ganapathy 1987). Models of condensation sequences in a gas of solar composition at 10E-3 bar predict that schreibersite condenses before Fe-Ni alloy (Sears 1978) or just after the Fe-Ni alloy (Petaev and Wood 2000; Lodders 2003). Conversely, schreibersite was proposed to exsolve from $\mathrm{Fe}-\mathrm{Ni}$ alloy at about $1000 \mathrm{~K}$ (Romig and Goldstein 1980; Kimura 1988). However, exsolution from $\mathrm{Fe}-\mathrm{Ni}$ alloy can not explain the schreibersite spherules enclosed within the sulfides.

In this study, we investigate competing hypotheses for the formation of EH3 kamacite, schreibersite, and perryite in order to constrain the history of the metalsulfide nodules. We consider the following hypotheses:

1. Condensation as a single phase with subsequent solid-state decomposition.

2. Condensation as separate phases.

3. Formation of perryite as a byproduct of sulfidation of Fe.

4. Re-crystallization of minerals after melting.
To test these hypotheses with trace elemental data we performed a detailed analysis of siderophile elements in Sahara 97072 by laser ablation, inductively coupled plasma mass spectrometry (ICP-MS).

\section{EXPERIMENTAL}

\section{SEM, Electron Microprobe Analysis (EMPA), and Petrographic Microscopy}

Five $13 \times 24 \mathrm{~mm}$ rectangular polished thin sections of Sahara 97072 were prepared without water. The thin sections were first studied and photographed using transmitted- and reflected-light petrographic microscopy. Element maps were made of 13 representative metal-sulfide nodules using an FEI XL30 scanning electron microscope (SEM) with a fieldemission gun and energy dispersive spectroscopy (EDS). Mapped elements include $\mathrm{Fe}, \mathrm{S}, \mathrm{P}, \mathrm{Ni}, \mathrm{Co}, \mathrm{Mg}, \mathrm{Si}, \mathrm{O}$, $\mathrm{C}, \mathrm{Mn}, \mathrm{Al}, \mathrm{Cu}, \mathrm{Cr}, \mathrm{Ca}, \mathrm{K}, \mathrm{Na}, \mathrm{N}$, and $\mathrm{Zn}$. Minerals were tentatively identified from element associations and then, using these maps as guides, various minerals were quantitatively analyzed for $\mathrm{Fe}, \mathrm{Ni}, \mathrm{Co}, \mathrm{Cr}, \mathrm{S}, \mathrm{P}, \mathrm{Si}, \mathrm{W}$, $\mathrm{Ti}, \mathrm{Zn}, \mathrm{Cu}, \mathrm{Mn}, \mathrm{Mg}, \mathrm{Ca}, \mathrm{Na}$, and $\mathrm{K}$ using a JEOL JXA-8600 (JEOL Ltd., Tokyo, Japan) electron microprobe. Standards were metal for $\mathrm{Fe}, \mathrm{Co}, \mathrm{Cr}, \mathrm{Ni}$, $\mathrm{Cu}$, and $\mathrm{W}$, synthetic $\mathrm{CrP}$ for $\mathrm{P}$, pyrite for $\mathrm{S}$, sphalerite for $\mathrm{Zn}$, rutile for $\mathrm{Ti}$, rhodochrosite for $\mathrm{Mn}$, wollastonite for $\mathrm{Ca}$, albite for $\mathrm{Na}$, olivine for $\mathrm{Si}$, and orthoclase for $\mathrm{K}$. Co concentrations were corrected for $\mathrm{Fe}$ interference by subtracting the average Co concentration detected in pure $\mathrm{Fe}$ metal from the measured concentrations in unknowns. Spot size was about $3 \mu \mathrm{m}$, with a $15 \mathrm{kV}$ accelerating voltage, a beam current of $15 \mathrm{nA}$, and $30 \mathrm{~s}$ 
counting time. Analyses were corrected using conventional ZAF procedures.

\section{Laser Ablation, Inductively Coupled Plasma Mass Spectrometry}

$\mathrm{Ni}, \mathrm{Cu}, \mathrm{Ga}, \mathrm{Ru}, \mathrm{Pd}$, Ir, and $\mathrm{Au}$ were measured using laser ablation, inductively coupled plasma mass spectrometry (LA-ICPMS) with a magnetic-sector, single-collector Thermo-Finnegan Element 2 ICP-MS (Thermo Scientific, Waltham, MA) coupled to a New Wave Research UP213 (New Wave Research, Fremont, CA) laser ablation unit. The mass spectrometer was operated in a dynamic peak-hopping mode, with mass/charge positioning achieved by a combination of magnetic current shifts and voltage offsets of the electrostatic analyzer (Hamester et al. 1999). The laserablation system was operated in aperture-imaging mode using a monochromatic beam of light at $213 \mathrm{~nm}$, which was generated from a frequency-quintupled, solid-state Nd-YAG source. This beam was focused onto a sample in a $3 \mathrm{~cm}^{3}$ ablation cell, which was continuously flushed to the plasma source of the mass spectrometer with about $1.1 \mathrm{~L} / \mathrm{min} \mathrm{He}$ gas. Minerals identified on element maps using energy-dispersive spectrometry and the electron microprobe equipped with wavelengthdispersive spectrometry were targeted for spot analyses; spot sizes varied from 8 to $40 \mu \mathrm{m}$. The beam was flashed on the sample at $7 \mathrm{~Hz}$ for approximately $40 \mathrm{~s}$ after approximately $20 \mathrm{~s}$ of collecting background signal with the shutter closed. The mass spectrometer collected data for ${ }^{57} \mathrm{Fe},{ }^{60} \mathrm{Ni},{ }^{63} \mathrm{Cu},{ }^{69} \mathrm{Ga},{ }^{101} \mathrm{Ru},{ }^{105} \mathrm{Pd},{ }^{193} \mathrm{Ir}$, and ${ }^{197} \mathrm{Au}$. Each analysis sequence consisted of two standard reference materials run before and after the data acquisition of 12 spots, except for the last sequence where 18 unknown spots were analyzed. The iron meteorites Filomena and Hoba were used as standards (Walker et al. 2008).

All data were processed using the LAMTRACE software (Achterbergh et al. 2001), which determines element concentrations based on ratios of backgroundsubtracted count rates for samples and standards, known concentrations in the standards, and an internal standard for the unknowns. The internal standard for kamacite analyses was the mean $\mathrm{Fe}$ concentration from 90 microprobe analyses of Sahara 97072 kamacite. The internal standard for the schreibersite analyses was the mean Fe concentration from nine microprobe analyses of Sahara 97072 schreibersite.

Using $\mathrm{Fe}$ as the internal standard for the perryite analyses required an estimation procedure as perryite $\mathrm{Fe}$ is variable and most LA-ICPMS analyses included some kamacite. Mean perryite $\mathrm{Fe}$ concentration from electron microprobe analyses have relative standard error of $8 \%$.
The mean $\mathrm{Fe}$ plus $\mathrm{Ni}$ concentration in perryite from electron microprobe analyses is $86 \mathrm{wt} \%$, with relative standard error of $2 \%$. One large perryite grain (labeled b05 in Fig. 2 and Table 1) analyzed with LA-ICPMS contains no kamacite. The internal Fe value for spot b05 was adjusted by trial and error so the $\mathrm{Fe}$ plus $\mathrm{Ni}$ concentration was $86 \mathrm{wt} \%$. The other spots contain a mixture of perryite and kamacite because of the small size of the perryite grains relative to the laser spots. As we did not know how much of each phase was in the ablation product, we estimated the $\mathrm{Fe}$ plus $\mathrm{Ni}$ concentration equaled about $95 \mathrm{wt} \%$, allowing $5 \mathrm{wt} \%$ for $\mathrm{Si}, \mathrm{Co}$, and $\mathrm{P}$. As $\mathrm{Ni}$ is concentrated in perryite, the $\mathrm{Ni}$ content thus calculated correlates with the perryite percentage in the analysis and is a measure of the reliability of the results. Relative error introduced by this method is likely $<10 \%$.

The detection limits for the LA-ICPMS measurements were set at the average background count rate plus three times the standard deviation of the background. All errors reported in this study are one standard deviation $(1 \sigma)$ of the counting statistics. Trace siderophile elements are normalized to $\mathrm{Ni}$ when compared with CI abundance.

\section{RESULTS}

\section{Mineralogy and Shock Features}

The mineralogy of Sahara 97096, which is paired with Sahara 97072, has been described by Weisberg and Prinz (1998). Metal-sulfide nodules in Sahara 97096 and Kota-Kota were described by Weisberg et al. (2006). Our results are consistent with these earlier descriptions. Sahara 97096 is listed as shock stage S2 in The Meteoritic Bulletin (Grossman 1998). We observe veins that appear to be shock melted with kamacite and troilite intergrown in myrmekitic-eutectic textures. These melt textures also occur on the edges of some nodules (Figs. 1a and 1e; Fig. 3). As also observed by Weisberg and Prinz (1998), niningerite can be either reverse-zoned in FeS (Fig. 1e) or normal-zoned (Fig. 1f). The normal-zoned niningerite has $\mathrm{Fe}$ concentration ranging from about $13 \mathrm{wt} \%$ near the edge with troilite to approximately $22 \mathrm{wt} \%$ in the interior. The reverse-zoned grain (center of nodule Fig. 1e) has Fe concentration ranging from about $17 \mathrm{wt} \%$ in the interior to approximately $24 \mathrm{wt} \%$ near the edge with troilite and about $21 \mathrm{wt} \%$ near the edge with kamacite. The reverse-zoned niningerite may be evidence of transient heating (Skinner and Luce 1971; Ehlers and El Goresy 1988). Preservation of the layered nodules as well as reverse and normally zoned niningerite indicates a highly unequilibrated meteorite with limited sulfide remobilization. 
กุ:

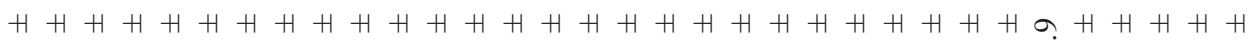

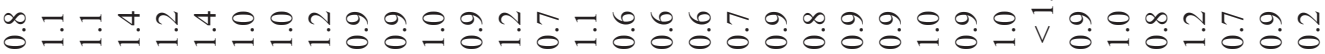

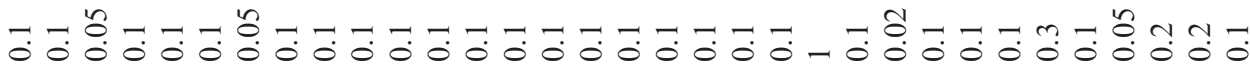

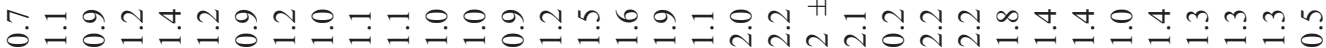

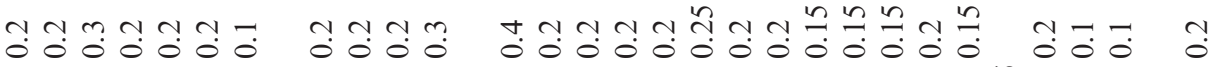

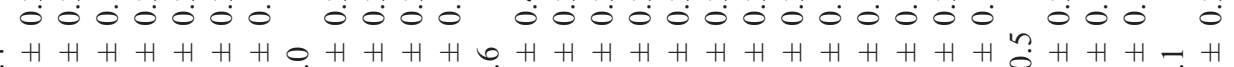

v

$\ddot{0} \ddot{0} \ddot{0}$

$H+H$

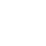

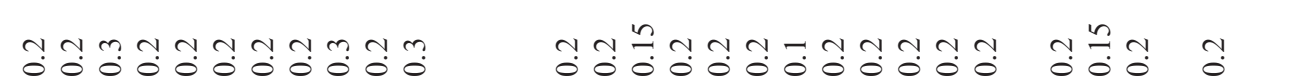

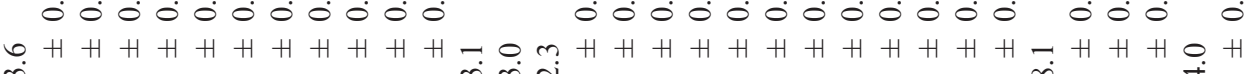

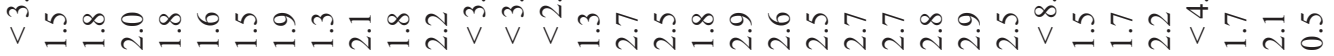

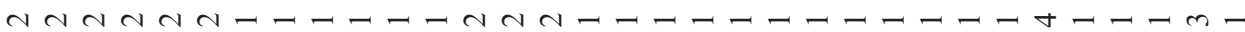

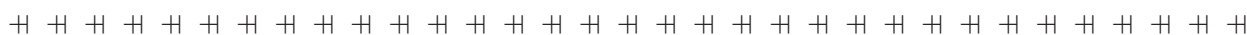

舟命宁

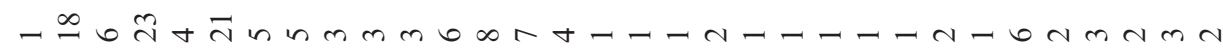

H H H H H H H H H H H H H H H H H H H H H H H H H H H H

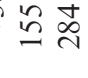

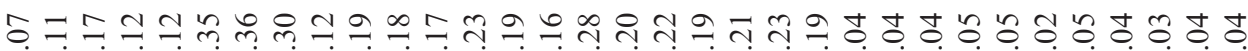

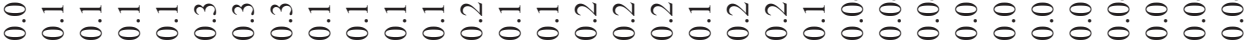

ले

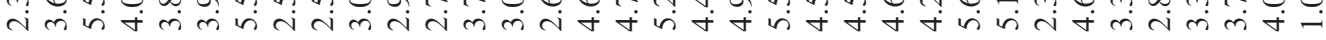


S. W. Lehner et al.

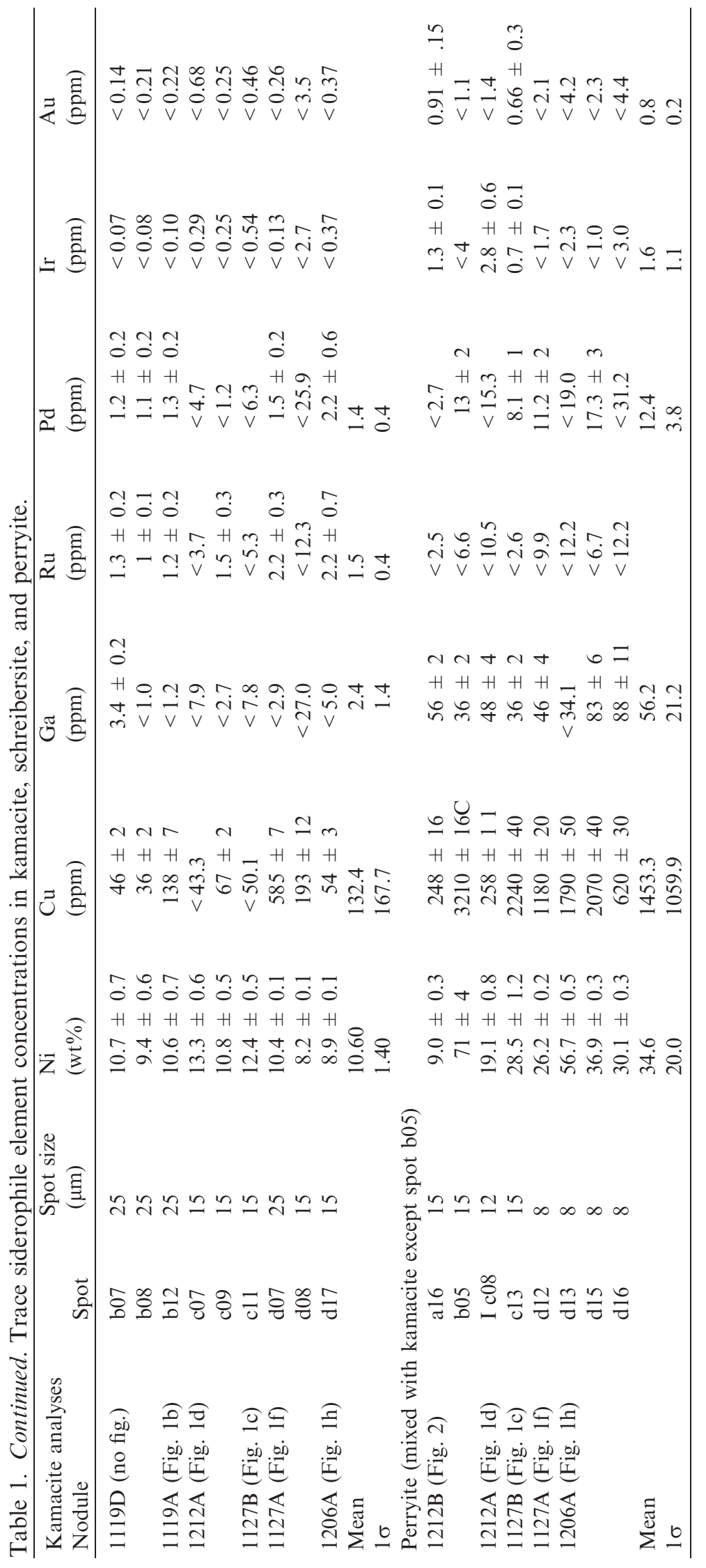




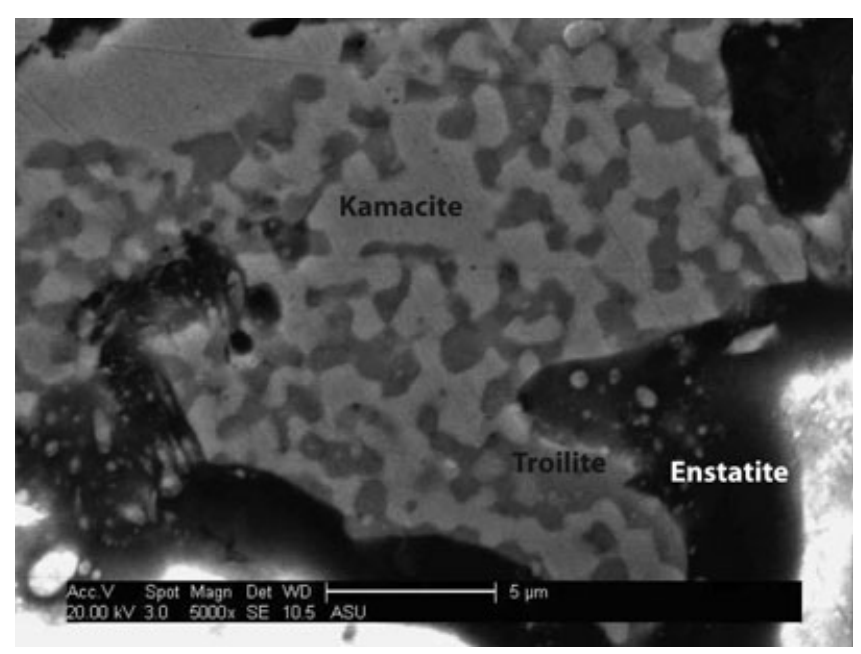

Fig. 3. Secondary electron image enlargement of the area in the white rectangle from Fig. 1e showing kamacite and troilite in myrmekitic-eutectic melt texture (Smith and Goldstein 1977; Scott 1982; Rubin 1985) near the edge of the metal-sulfide nodule. The bright areas near the bottom corners represent charging of the enstatite.

Thirteeen metal-sulfide nodules were examined in this work. They range from 150 to $800 \mu \mathrm{m}$ in diameter. Most are predominantly kamacite with one or more minerals in their centers and appear to be concentrically zoned (Fig. 1). The core minerals are schreibersite, oldhamite, niningerite, graphite, and less commonly silica (Fig. 1). Troilite occurs near the core and in layers at the periphery of the nodules. Some nodules appear to be agglomerations of smaller spheroidal objects (Figs. 1f, 1h, and 1i). Although some nodules are predominantly sulfide, we chose nodules that were representative of the different metal dominated types. They contain: oldhamite cores (Figs. $1 \mathrm{a}$ and 1h), concentric silicate rings (Figs. 1a and 1b), graphiteschreibersite cores (Figs. 1b, 1c, 1f, 1g, and 1i), primarily kamacite (Fig. 1d), and oldhamite-niningeritetroilite cores (Figs. 1e and 1f). Some nodules contain fine-grained sulfides enclosing large grains of djerfisherite (Figs. 1c, 1f, and 1g). In Qingzhen, the finegrained sulfides were interpreted as reaction products of djerfisherite (El Goresy 1985). Several nodules contain daubreelite enclosed in troilite with exsolution lamellae having high $\mathrm{Cr}$ concentrations. One nodule contains a large grain of high-iron sphalerite (Fig. 1h).

All 13 metal-sulfide nodules were mapped with SEM EDS, all but one were studied with EMPA. We analyzed 90 points in kamacite, 16 points in perryite, 9 points in schreibersite, and 19 points in troilite with EMPA to obtain the averages in Table 2. Kamacite, perryite, and schreibersite in seven of the nodules were measured with LA-ICPMS for trace siderophile
Table 2. Average major element concentrations from electron microprobe analyses.

\begin{tabular}{lcccc}
\hline wt $\%$ & Kamacite & Perryite & Schreibersite & Troilite \\
\hline $\mathrm{Fe}$ & $92.9 \pm 2.5$ & $17.3 \pm 1.4$ & $70.5 \pm 1.2$ & $58.6 \pm 2.6$ \\
$\mathrm{Ni}$ & $4.0 \pm 1.4$ & $68.6 \pm 1.6$ & $13.2 \pm 0.4$ & $0.15 \pm 0.25$ \\
$\mathrm{P}$ & $0.1 \pm 0.4$ & $3.7 \pm 0.3$ & $16 \pm 1.2$ & na \\
$\mathrm{Si}$ & $2.5 \pm 0.4$ & $11.5 \pm 0.2$ & $0.18 \pm 0.02$ & na \\
$\mathrm{Co}$ & $0.4 \pm 0.03$ & $0.1 \pm 0.05$ & $0.07 \pm 0.02$ & na \\
Modal $\%{ }^{\mathrm{a}}$ & 58.2 & 2.8 & 1.4 & 37.5 \\
\hline
\end{tabular}

na $=$ not analyzed.

${ }^{\mathrm{a}}$ Calculated from mass balance equations and EPMA results.

elements, with the results given in Table 1. Shown in Figs $1 \mathrm{~b}, 1 \mathrm{c}, 1 \mathrm{~d}, 1 \mathrm{f}, 1 \mathrm{~h}$, and 2 are the spots analyzed in six of the seven nodules studied with LA-ICPMS. The remaining nodule is not shown.

\section{Electron Microprobe Analyses}

The composition of kamacite near perryite and schreibersite indicates that $\mathrm{Ni}$ concentration decreases away from perryite and schreibersite consistent with $\mathrm{Ni}$ diffusing out of the high-Ni phases. This observation accords with the lack of perryite in EH4 and EH5 meteorites and the hypothesis that perryite is a primitive mineral that was reabsorbed into kamacite during metamorphism (Easton 1986).

The $\mathrm{Ni}$ versus $\mathrm{Fe}$ concentrations for all three minerals plot near a line with slope of -1.3 . (Fig. 4a). $\mathrm{Si}$ versus $\mathrm{Fe}$ (Fig. 4b) as well as $\mathrm{P}$ and $\mathrm{Si}$ versus $\mathrm{Ni}$ (Figs. 4c and 4d) are nearly linear for kamacite and perryite but not for schreibersite. Kamacite averages $93 \mathrm{wt} \% \mathrm{Fe}, 4 \mathrm{wt} \% \mathrm{Ni}$, and $2.5 \mathrm{wt} \% \mathrm{Si}$. Ni and $\mathrm{Si}$ are concentrated in the perryite, and $\mathrm{P}$ is dominantly in the schreibersite (Table 2). The average stoichiometry of the perryites is $(\mathrm{FeNi})_{14}(\mathrm{SiP})_{5}$ which is slightly more metal-rich than the commonly accepted stoichiometry of $(\mathrm{FeNi})_{5}(\mathrm{SiP})_{2}$ reported by El Goresy et al. (1988) in Qingzhen and Yamato 691. The perryite formula has also been reported as $(\mathrm{FeNi})_{8}(\mathrm{SiP})_{3}$ (Okada et al. 1991).

\section{Trace Siderophile Elements from LA-ICPMS}

In kamacite, ratios of $\mathrm{Ru} / \mathrm{Ir}, \mathrm{Pd} / \mathrm{Ir}$, and $\mathrm{Pd} / \mathrm{Ru}$ cluster around their respective $\mathrm{CI}$ values (Fig. 5a). Ru, $\mathrm{Ir}$, and $\mathrm{Pd}$ (Table 1) correlate with $\mathrm{Ni}$ and plot just below and parallel to the $\mathrm{CI}$ ratio (Fig. 5b). Au, Ga, and $\mathrm{Co}$ are enriched in kamacite relative to their respective $\mathrm{CI}$ element/Ni ratios, whereas $\mathrm{Cu}$ is depleted (Fig. 6). All elements plot near the intersection of the equilibrium condensation trajectory for the elements versus $\mathrm{Ni}$ and their respective $\mathrm{CI}$ ratios (Figs. 5 and 6). 

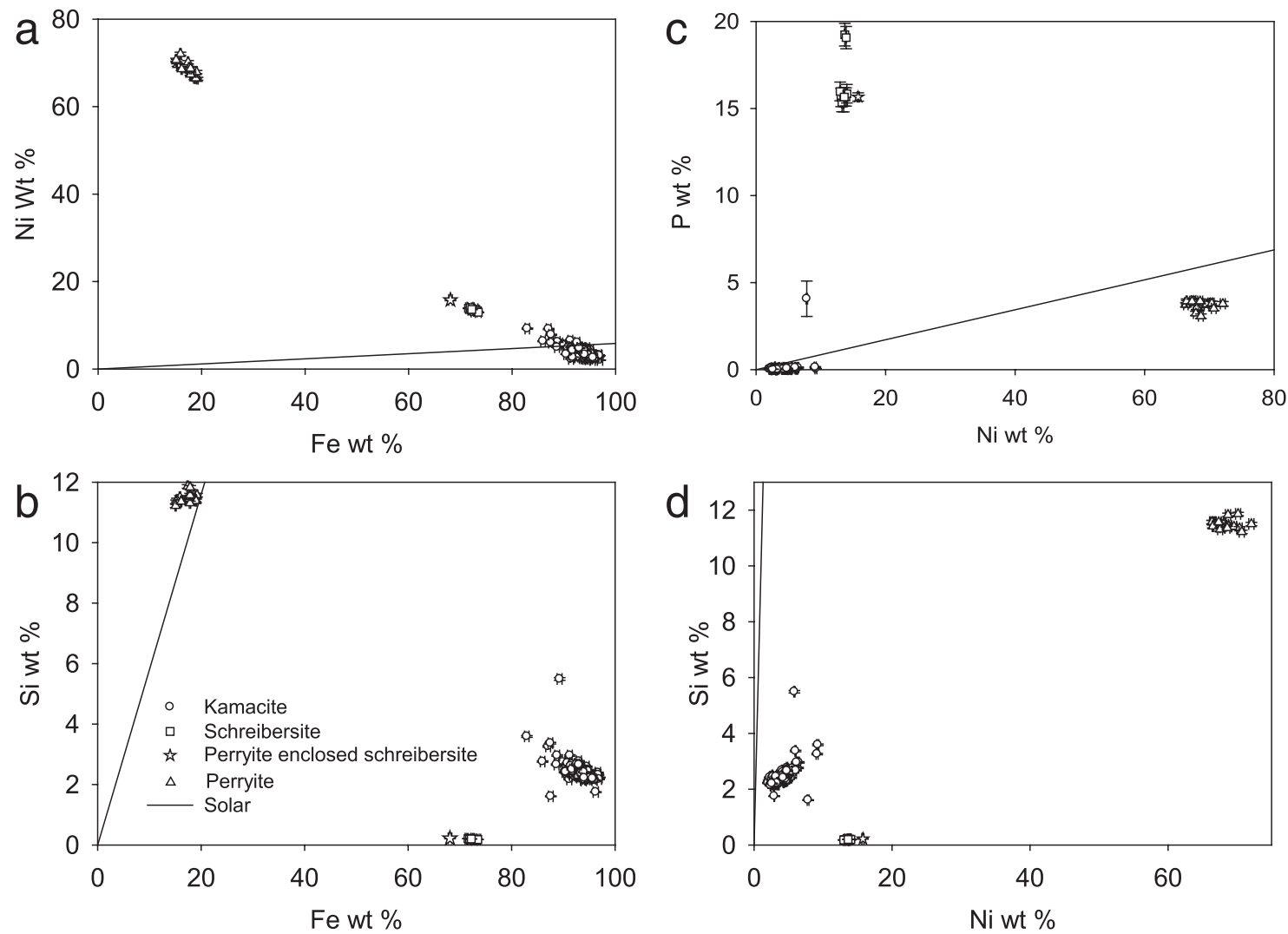

Fig. 4. Electron microprobe analyses showing relationships for a) $\mathrm{Ni}$ and b) $\mathrm{Si}$ concentrations as a function of Fe concentrations. Semi-linear plots of c) P and d) Si concentrations as a function of Ni concentrations. Solid lines represent the solar ratio. The data point represented by the star is a schreibersite enclosed by perryite.

In schreibersite, the $\mathrm{Pd} / \mathrm{Ru}$ ratio is near the CI value (Fig. 5a), although $\mathrm{Ru}$ and $\mathrm{Pd}$ are slightly more depleted relative to $\mathrm{Ni}$ and $\mathrm{CI}$ in schreibersite than in kamacite (Fig. 5b). Cu is also more depleted relative to CI in schreibersite than in kamacite (Fig. 6). One anomalously high $\mathrm{Cu}$ value was measured near djerfisherite. Either beam overlap or analysis of djerfisherite at depth is suspected here. Ga was detected in only two of the 12 schreibersite analyses, and Ir and $\mathrm{Au}$ are below detection limits (Table 1).

In perryite analyses containing some fraction of kamacite, $\mathrm{Cu}$ (Fig. 6) and Pd correlate with $\mathrm{Ni}$ parallel to the $\mathrm{CI}$ ratio. $\mathrm{Ru}$, Ir, and $\mathrm{Au}$ are below detection limits in the perryite (Table 1). The Ga concentration is similar to kamacite.

\section{DISCUSSION}

\section{Constraints from Sulfides}

The FeS content of niningerite in contact with troilite positively correlates with temperature (Skinner and Luce 1971). Reverse zoning, with niningerite FeS concentration decreasing toward the center, implies a heating event (Skinner and Luce 1971; Ehlers and El Goresy 1988). The occurrence of both reversely zoned and normally zoned niningerite within the same Sahara 97072 thin section suggests the metal-sulfide nodules experienced preaccretionary thermal events as proposed for Qingzhen (Lin and El Goresy 2002) because the zoning would have been homogenized by parent body processes. A minimum niningerite formation temperature of $730 \mathrm{~K}$ is suggested by extrapolating the niningerite-troilite geothermometer using the average FeS concentration (23 formula \%, 38 microprobe measurements), although linear extrapolation may be misleading below 34 formula \% FeS corresponding to 773K (Skinner and Luce 1971).

The djerfisherite in Sahara 97072 is associated with breakdown products indicative of a metamorphic reaction (El Goresy 1985). This reaction represents a late parent-body thermal event at $<630 \mathrm{~K}$ and probably of short duration in Qingzhen and Yamato 691 (Lin and El Goresy 2002). In Sahara 97072, evidence of a possible late thermal event can be seen by comparing the $\mathrm{Ni}$ correlation of elements in the 

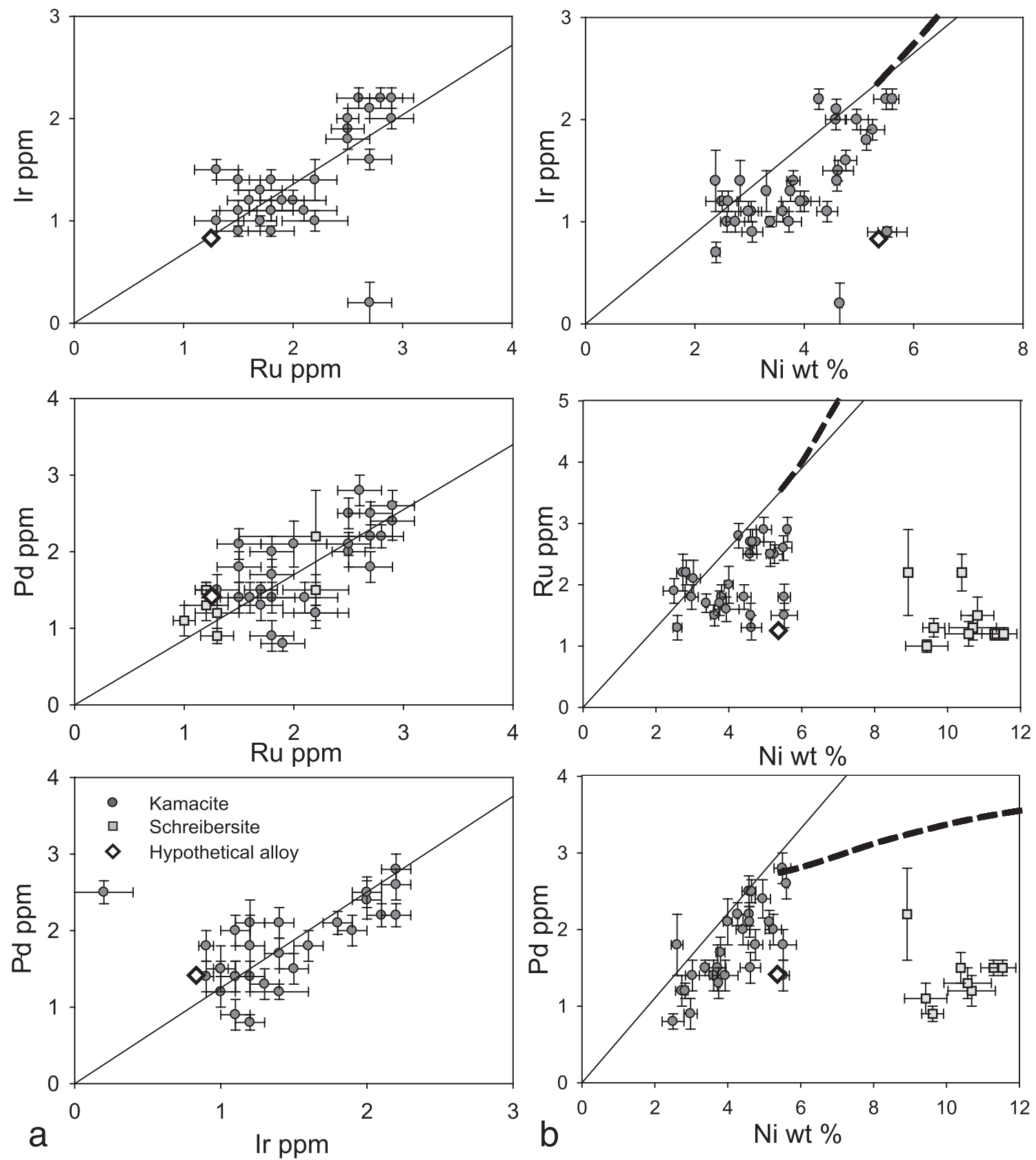

Fig. 5. a) Relationships among Ir, $\mathrm{Ru}$, and $\mathrm{Pd}$. b) Each point represents $\mathrm{Ir}$, $\mathrm{Ru}$, or Pd concentration as a function of $\mathrm{Ni}$ concentration. The large diamond is the hypothetical alloy composition. Circles are kamacite analyses and squares represent schreibersite analyses. Solid lines are solar ratios. Dashed lines are equilibrium trajectories of alloy condensation from a solar gas at $10 \mathrm{~Pa}$ total pressure; adapted from Campbell et al. (2005a).

kamacite with low diffusion coefficients (Ir and Pd) with the more diffusive elements $(\mathrm{Cu}, \mathrm{Co}, \mathrm{Ru}, \mathrm{Au}$, and $\mathrm{Ga})$ which are not correlated with $\mathrm{Ni}$ (Figs. 5 and 6). It is possible that element exchange between sulfides and metal occurred during such an event. We will now consider how our results accord with the hypotheses listed in the introduction for the formation of kamacite, schreibersite, and perryite.

\section{Condensation as a Single Phase with Subsequent Decomposition}

To investigate whether a condensate precursor alloy could have subsequently decomposed into kamacite, perryite, and schreibersite we tested if their compositions could be reasonably recombined with the $\mathrm{Fe}$ in troilite to match $\mathrm{CI}$ chondrite proportions of 

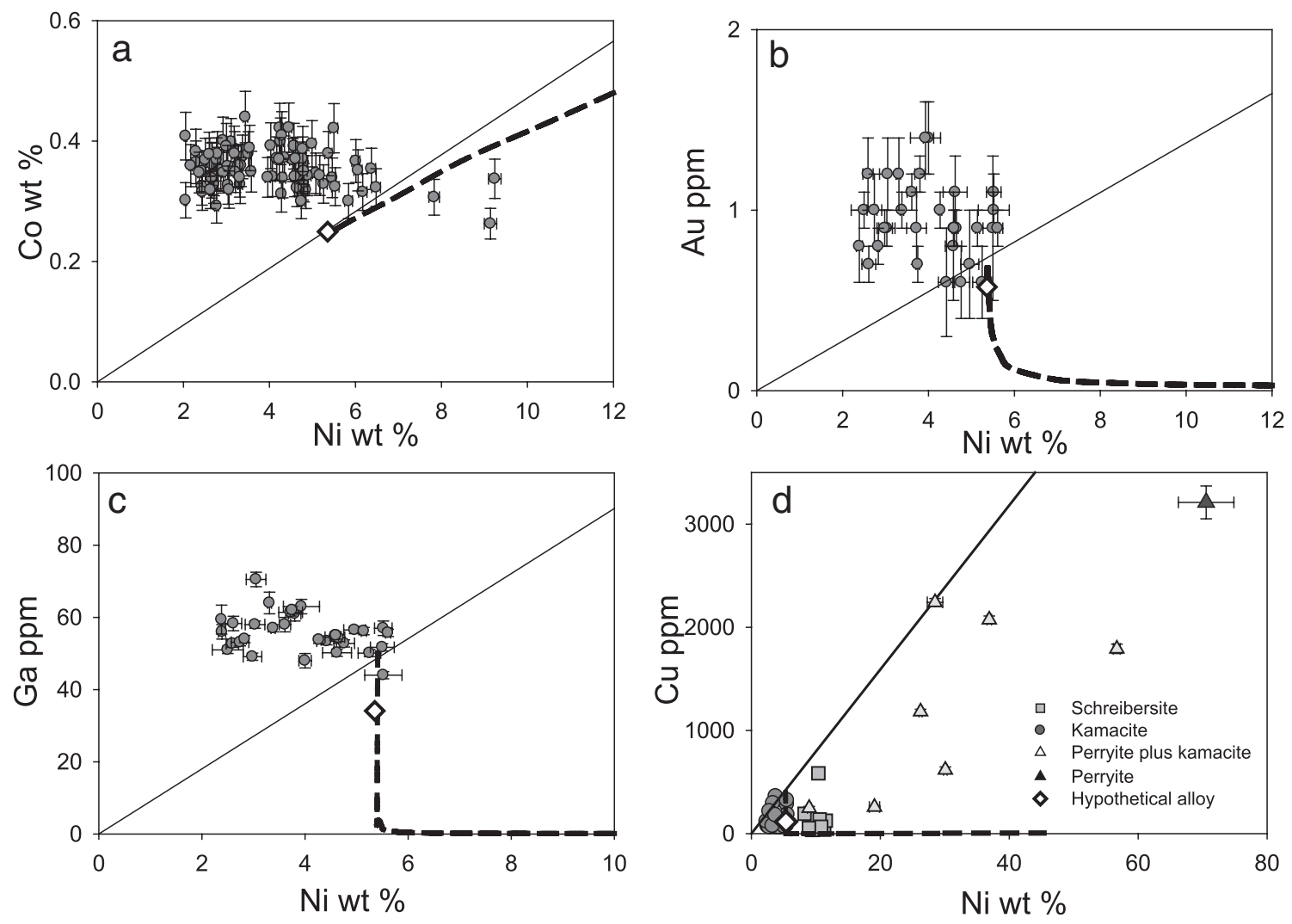

Fig. 6. a) $\mathrm{Co}, \mathrm{b}) \mathrm{Au}, \mathrm{c}) \mathrm{Ga}$, and d) $\mathrm{Cu}$ concentration versus $\mathrm{Ni}$ concentration. Triangles are perryite analyses and the other symbols are as in Fig. 5. Solid lines are solar ratios. Dashed lines are equilibrium trajectories of alloy condensation from a solar gas at $10 \mathrm{~Pa}$ total pressure; adapted from Campbell et al. (2005a). Co trajectory is from Campbell and Humayun (2004).

siderophile elements. The concentrations of major elements in such a hypothetical alloy were calculated from the mean values measured with electron microprobe (Table 2) weighted by modal percentage of troilite, kamacite, perryite, and schreibersite. In this simplified system, troilite is a proxy for all $\mathrm{Fe}$ containing sulfides such as sphalerite, niningerite, and djerfisherite. The modal percentages were calculated from mass balance equations constrained by CI ratios.

We determined that an assemblage with approximately 58.2 modal \% kamacite, 2.8 modal \% perryite, 1.4 modal \% schreibersite, and the $\mathrm{Fe}$ from 37.5 modal \% troilite (Tables 2 and 3) could form a precursor alloy with CI chondritic ratios (Lodders 2003) of $\mathrm{Co} / \mathrm{Ni}, \mathrm{P} / \mathrm{Ni}$, and $\mathrm{Fe} / \mathrm{Ni}$. The non-sulfide portion of the metal sulfide nodules would be about 93 modal \% kamacite, 4.5 modal \% perryite, and 2.3 modal \% schreibersite consistent with our modal estimates of these minerals. The modes are within the range for individual metal-sulfide nodules from Yamato 691 (Kimura 1988) and similar to other estimates for EH chondrites (McKinley et al. 1984; Kallemeyn and Wasson 1986; Weisberg and Prinz 1998). Using the non- sulfide percentages of kamacite, schreibersite, and perryite produces an alloy in which the $\mathrm{Fe} / \mathrm{Ni}$ ratio is $73 \%$ of $\mathrm{CI}$, indicating about $27 \%$ of the $\mathrm{Fe}$ is in sulfides and silicates, similar to the value of $\mathrm{Fe}$ in $\mathrm{Fe}-\mathrm{Ni}$ alloy for EH chondrites (Campbell et al. 2005b).

To calculate the precursor metal composition, the elemental sulfur was eliminated from the troilite modal percentage and the resulting low total was then normalized to $100 \%$. The hypothetical precursor composition is $5.35 \mathrm{wt} \% \mathrm{Ni}, 91.83 \mathrm{wt} \% \mathrm{Fe}, 0.46 \mathrm{wt} \%$ $\mathrm{P}, 2.11 \mathrm{wt} \% \mathrm{Si}$, and $0.25 \mathrm{wt} \%$ Co (Table 3). This model assumes the precursor alloy later reacted with gas species such as $\mathrm{H}_{2} \mathrm{~S}$ to form sulfide.

Applying our calculated modal percentages as weighting factors to recombine the average trace element compositions measured with LA-ICPMS in kamacite, perryite, and schreibersite yields a Fe-Ni alloy (Table 3) in which $\mathrm{Pd}$ is enriched compared with $\mathrm{Ru}$ and Ir, consistent with EC bulk analyses (Horan et al. 2003) showing refractory element depletion relative to $\mathrm{Ni}$ (Larimer and Wasson 1988; Hutson and Ruzicka 2000). In the hypothetical $\mathrm{Fe}-\mathrm{Ni}$ alloy, the $\mathrm{Ir} / \mathrm{Ru}$, $\mathrm{Ga} / \mathrm{Cu}, \mathrm{Au} / \mathrm{Pd}, \mathrm{Cu} / \mathrm{Pd}$, and $\mathrm{Ga} / \mathrm{Pd}$ ratios are closer to 
Table 3. Composition of mean EH magnetic fraction, kamacite hypothetical alloy, $\mathrm{Cl}$, and bulk $\mathrm{EH}$ chondrite.

\begin{tabular}{lccccc}
\hline & $\begin{array}{c}\text { EH } \\
\text { magnetic } \\
\text { fraction }^{\mathrm{b}}\end{array}$ & Kamacite & $\begin{array}{l}\text { Hypothetical } \\
\text { alloy }\end{array}$ & $\mathrm{Cl}^{\mathrm{c}}$ & $\begin{array}{c}\text { Bulk } \\
\mathrm{EH}^{\mathrm{d}}\end{array}$ \\
\hline $\mathrm{Ir}(\mathrm{ppm})$ & 2.1 & 1.3 & 0.8 & 0.5 & 0.6 \\
$\mathrm{Ru}(\mathrm{ppm})$ & 3.5 & 2.1 & 1.2 & 0.7 & 0.9 \\
$\mathrm{Ni}(\mathrm{wt} \%)$ & 6.0 & 4.0 & 5.3 & 1.1 & 1.8 \\
$\mathrm{Co}(\mathrm{wt} \%)$ & 0.34 & 0.36 & 0.25 & 0.05 & 0.09 \\
$\mathrm{Fe}(\mathrm{wt} \%)$ & 90 & 93 & 92 & 18 & 29 \\
$\mathrm{Pd}(\mathrm{ppm})$ & 3.7 & 1.8 & 1.4 & 0.6 & 0.9 \\
$\mathrm{Si}(\mathrm{wt} \%)$ & $\mathrm{NA}$ & 2.5 & 2.1 & 11 & 17 \\
$\mathrm{P}(\mathrm{wt} \%)$ & $\mathrm{NA}$ & 0.1 & 0.5 & 0.1 & 0.2 \\
$\mathrm{Au}(\mathrm{ppm})$ & 1.4 & 0.9 & 0.6 & 0.1 & 0.3 \\
$\mathrm{Cu}(\mathrm{ppm})$ & 316 & 123 & 115 & 127 & 200 \\
$\mathrm{Ga}(\mathrm{ppm})$ & 59 & 56 & 34 & 10 & 14 \\
\hline $\mathrm{Selected} \mathrm{ratios}$ & & & & \\
\hline $\mathrm{Ir} / \mathrm{Ru}$ & 0.6 & 0.6 & 0.7 & 0.7 & 0.7 \\
$\mathrm{Cu} / \mathrm{Pd}$ & 85 & 69 & 81 & 228 & 222 \\
$\mathrm{Pd} / \mathrm{lr}$ & 1.8 & 1.3 & 1.7 & 1.2 & 1.5 \\
$\mathrm{Pd} / \mathrm{Ru}$ & 1.1 & 0.9 & 1.1 & 0.8 & 1.0 \\
$\mathrm{Ga} / \mathrm{Pd}$ & 16 & 31 & 24 & 17 & 16 \\
$\mathrm{Fe} / \mathrm{Co}$ & 265 & 262 & 370 & 360 & 321 \\
$\mathrm{Au} / \mathrm{Pd}$ & 0.4 & 0.5 & 0.4 & 0.3 & 0.3 \\
$\mathrm{Ga} / \mathrm{Cu}$ & 0.2 & 0.5 & 0.3 & 0.1 & 0.1 \\
$\mathrm{Co} / \mathrm{Ni}$ & 0.06 & 0.09 & 0.05 & 0.05 & 0.05 \\
\hline $\mathrm{Listed}$ & & & & &
\end{tabular}

${ }^{\mathrm{a}}$ Listed in reverse order of volatility.

${ }^{\mathrm{b}}$ Kong et al. (1997).

${ }^{\mathrm{c}}$ Lodders (2003).

${ }^{\mathrm{d}}$ Wasson and Kallemeyn (1988).

the CI value than in the kamacite (Table 3), but the $\mathrm{Pd} / \mathrm{Ru}$ and $\mathrm{Pd} / \mathrm{Ir}$ ratios are higher and closer to bulk $\mathrm{EH}$ and mean EH magnetic fraction (Figs. 5 and 6). Au and $\mathrm{Ga}$ are not enriched over $\mathrm{CI}$ (normalized to $\mathrm{Ni}$ ) as they are in the kamacite (Fig. 6), although $\mathrm{Au}$ is enriched in EC bulk analysis (Larimer and Wasson 1988; Wasson and Kallemeyn 1988). Otherwise, the composition of the hypothetical precursor alloy resembles the composition of mean EH magnetic separates with additional $\mathrm{Fe}$ (Kong et al. 1997) (Table 3).

If we consider that schreibersite and perryite are decomposition products formed as the cooling precursor alloy became saturated in $\mathrm{Si}$ and $\mathrm{P}$, we can account for the distribution within the kamacite of perryite and possibly schreibersite. More complexity is required to explain the schreibersite spherules enclosed within the sulfides or the perryite at the interface of kamacite and troilite. In addition, the ratio of $\mathrm{Ru} / \mathrm{Pd}$ in schreibersite is close to the CI ratio (1.05 in schreibersite from this study versus 1.07 in CI chondrites from Lodders [2003]) (Fig. 5a). A CI Ru/Pd ratio in schreibersite that formed by decomposition of an alloy would require that the two elements have similar diffusive behavior in a kamacite-schreibersite system. However, diffusion experiments in $\mathrm{Fe}-\mathrm{Ni}$ alloy reveal that $\mathrm{Ru}$ has a diffusion constant three orders of magnitude higher than Pd which results in a significant difference in their diffusive behavior at temperatures below $1523 \mathrm{~K}$ (Righter et al. 2005), making CI proportions of these elements unlikely to have resulted from decomposition.

Perryite exsolution from kamacite is also problematic in that perryite contains significant $\mathrm{Cu}, \mathrm{Ga}$, and $\mathrm{Pd}$. In Fe-Ni alloy $\mathrm{Pd}$ has a diffusion constant three orders of magnitude lower than $\mathrm{Ga}$ and 10 times lower than $\mathrm{Cu}$ (Righter et al. 2005). However, the element/Ni ratios in the hypothetical alloy lie on or near their condensation trajectories (Campbell and Humayun 2004; Campbell et al. 2005a) (Figs. 5 and 6) indicating such an alloy is plausible. Whether perryite formed at high temperature or at low temperature by exsolution is unresolved. We next consider the hypothesis that schreibersite and perryite condensed separately and agglomerated into the Fe-Ni alloy.

\section{Condensation as Separate Phases}

\section{Schreibersite}

Lin and El Goresy (2002) proposed that schreibersite spherules were molten drops at the time of oldhamite and niningerite condensation and that schreibersite was the earliest phase to condense in Qingzhen metal-sulfide nodules. Schreibersite spherules too small to analyze with LA-ICPMS methods used in this study also occur in sulfides of Sahara 97072 metalsulfide nodules and large schreibersite grains within the kamacite have a $\mathrm{Ru} / \mathrm{Pd}$ ratio close to bulk CI, indicating no fractionation has occurred between these two elements.

The condensation hypothesis for the origin of schreibersite requires an explanation for the lack of $\mathrm{Ir}$ which is below detection limits in schreibersite. The fractionation of $\mathrm{Ir}$ from $\mathrm{Ru}$ and $\mathrm{Pd}$ between schreibersite and both taenite and kamacite was observed in CAI fremdlinge EM1 in Efremovka CAI Ef1 (Campbell et al. 2003), where the reported Ru/Pd ratio in schreibersite was at least 10 with $\mathrm{Pd}$ under detection limits. Ir concentration in the schreibersite, also under detection limits, was at least three orders of magnitude below $\mathrm{Ru}$ concentration which may suggest Ir is incompatible in the schreibersite structure.

As explained by Munir Humayun (personal communication), "since $\mathrm{Fe}$ and $\mathrm{Ni}$ are condensed before $\mathrm{P}$, the condensation reaction that forms schreibersite is one of $\mathrm{P}($ vapor $)+\mathrm{Fe}($ metal $)=\mathrm{Fe}_{3} \mathrm{P}$ (solid). Thus, the schreibersite will tend to inherit refractory elements from the metal. If diffusive equilibrium can be 
maintained between phosphide and metal, then the metal may be depleted in $\mathrm{Ru}$ relative to $\mathrm{Ir}$ by preferential partitioning of $\mathrm{Ru}$ into phosphide. The temperature dependence of the partitioning must be known to distinguish between condensation reactions and subsolidus metal exsolution." This idea could be investigated by carefully measuring $\mathrm{Ru}$ and $\mathrm{Ir}$ in kamacite near schreibersite inclusions. The depletion of $\mathrm{Ru}$ relative to $\mathrm{Ir}$ was not evident in our kamacite analyses (Fig. 5).

\section{Perryite and Kamacite}

For perryite, Kallemeyn and Wasson (1986) suggested a condensation origin citing the lack of equilibrium in the EH3s. Dambaev and Ulyanov (1998) cite textural evidence to suggest perryite formed before daubreelite exsolution from troilite at $1253 \mathrm{~K}$ in PCA 91085 (EH3). Condensation with partial isolation calculations (Petaev and Wood 1998) suggest that Si begins to condense into metal around $1200 \mathrm{~K}$. Our results provide no indication whether or not perryite was an early condensate.

In kamacite, the near $\mathrm{CI}$ proportions of $\mathrm{Ir}, \mathrm{Ru}$, and Pd suggest a condensation origin. The $\mathrm{Ni}$ normalized enrichment of $\mathrm{Co}, \mathrm{Ga}$, and $\mathrm{Au}$ (Fig. 6) in kamacite results from $\mathrm{Ni}$ being sequestered in perryite and $\mathrm{Fe}$ in troilite, although it is unclear whether perryite formed before or after the alloy condensed. All elements in kamacite plot where the condensation trajectories coincide with the CI ratio implying the alloy remained in equilibrium with a cooling nebular gas down to at least $\mathrm{Ga}$ condensation temperature about $970 \mathrm{~K}$ (Lodders 2003) (Figs. 5 and 6). Therefore, an origin as separate condensates for kamacite, schreibersite, and perryite is possible.

\section{Formation of Perryite by Sulfidation of Fe}

Rambaldi et al. (1986) proposed perryite to be a product of sulfidation of $\mathrm{Fe}-\mathrm{Ni}$ metal, citing its occurrence at the interface of kamacite and sulfides. It is plausible that much perryite was formed at cooler temperatures when the sulfidation of the $\mathrm{Fe}$ (approximately 650-700 K) (Lauretta et al. 1997) concentrated $\mathrm{Ni}$ and $\mathrm{Si}$ in kamacite. This perryite is concentrated at the kamacite interface with troilite and sulfides including djerfisherite and sphalerite. However, the sulfidation hypothesis requires more complexity to explain perryite inclusions in kamacite (Fig. 2) not associated with sulfide and ubiquitous perryite near the outside edge of the metal-sulfide nodules in contact with silicate matrix and chondrules. Some of these perryites may have been associated with sulfides which were in the material removed when making the thin section.
Laser ablation, inductively coupled plasma mass spectrometry analyses indicate perryite contains $\mathrm{Cu}, \mathrm{Ga}$, and $\mathrm{Pd}$ with no $\mathrm{Ir}$ or $\mathrm{Ru}$. Because of spot size limitations, these analyses were of the larger perryite inclusions which tend to be near the edges of the metalsulfide nodules and near the kamacite interface with sulfides. Pd is a siderophile element with a very low diffusion constant in $\mathrm{Fe}-\mathrm{Ni}$ alloy and its presence is inconsistent with inadvertent ablation of sulfides as a source of the high $\mathrm{Cu}$ and $\mathrm{Ga}$ measured in perryite. The $\mathrm{Cu}, \mathrm{Ga}$, and $\mathrm{Pd}$ measured in large perryite grains suggest later processing, as discussed below.

\section{Re-Crystallization of Minerals after Melting}

$\mathrm{Cu}, \mathrm{Ga}$, and $\mathrm{Pd}$ are incompatible in a solid/liquid $\mathrm{Fe}-\mathrm{Ni}$ alloy system and $\mathrm{Ir}$ and $\mathrm{Ru}$ are compatible meaning they prefer the solid phase (Kelly and Larimer 1977; Chabot and Jones 2003; Chabot et al. 2006; Walker et al. 2008). Therefore, to estimate the plausibility of perryite crystallizing from a melt in the presence of solid kamacite we reviewed the following ternary phase diagrams: $\mathrm{Fe}, \mathrm{Ni}$, Si (Ackerbauer et al. 2009); Fe, Ni, S (Waldner and Pelton 2004); and Fe, Ni, P; Fe, P, Si; and Fe, P, S (Raghavan 1988a, 1988b).

In the Fe-Ni-P system, a phase similar to perryite, $\mathrm{Ni}_{5} \mathrm{P}_{2}$, is in equilibrium with liquid, $\mathrm{Fe}_{2} \mathrm{P}$, and schreibersite at approximately $1243 \mathrm{~K}$. In the $\mathrm{Fe}, \mathrm{Ni}, \mathrm{Si}$ system a perryite-like phase, $\mathrm{Ni}_{31} \mathrm{Si}_{12} / \mathrm{Ni}_{5} \mathrm{Si}_{2}$, containing up to 20 atomic $\% \mathrm{Fe}$ melts between 1386 and $1423 \mathrm{~K}$. The melting temperature of perryite $\left[(\mathrm{FeNi})_{14}(\mathrm{SiP})_{5}\right.$, this study] is likely to be lower that these pure $\mathrm{Ni}-\mathrm{Si}$ phases because melting experiments of Indarch (EH4), show Fe-Ni alloy and sulfide were liquid by $1270 \mathrm{~K}$ in the form of an immiscible Si-rich melt and two sulfide melts (McCoy et al. 1999).

In the Fe-Ni binary system, Fe-Ni alloy of kamacite composition $(<7 \quad \mathrm{wt} \% \mathrm{Ni})$ melts at approximately $1790 \mathrm{~K}$ depending on minor element concentration (Raghavan 1988b). However, there is a eutectic melting reaction with $\mathrm{FeS}$ at approximately $1250 \mathrm{~K}$ (Kullerud and Yoder 1959; Raghavan 1988a) and therefore, recrystallization of perryite from Si-rich melt could have occurred at the interface of $\mathrm{Fe}-\mathrm{Ni}$ alloy and troilite if the metal-sulfide nodules were briefly heated to approximately $1300 \mathrm{~K}$. Textural evidence, such as the three nodules molded into one, (Fig. 1h) or kamacite and troilite in eutectic melt texture near the edges of the nodules (Figs. 1a, 1e, and 3) suggests the metal-sulfide nodules may have been exposed to eutectic temperatures and partially melted.

Information is not available on partitioning behavior of siderophile elements between solid kamacite and liquid of perryite composition but the $\mathrm{Fe}, \mathrm{Ni}, \mathrm{P}$; 
Fe, $\mathrm{P}, \mathrm{Si}$; $\mathrm{Fe}, \mathrm{P}, \mathrm{S}$, and $\mathrm{Fe}, \mathrm{Ni}, \mathrm{S}$ ternary phase diagrams from metallurgical studies suggest such a system is possible (Raghavan 1988a, 1988b; Waldner and Pelton 2004). Perryite formed at this interface by earlier sulfidation may have been melted, and these circumstances could explain why the $\mathrm{Cu}, \mathrm{Ga}$, and $\mathrm{Pd}$, which are incompatible in a solid/liquid $\mathrm{Fe}-\mathrm{Ni}$ alloy system are incorporated into perryite with no measurable compatible elements (Ru and Ir) (Table 1).

The schreibersite which we analyzed was not close to the kamacite-troilite interface and does not appear to have formed from a melt. Partitioning experiments show that $\mathrm{Ru}$ partitions into P-rich liquid in a solid/liquid Fe-Ni-P system and $\mathrm{Pd}$ partitioning is unaffected by $P$ content (Corrigan et al. 2009), and therefore schreibersite precipitation from a melt would not likely preserve a $\mathrm{Ru} / \mathrm{Pd}$ ratio close to $\mathrm{CI}$ as observed.

In kamacite analyzed away from the interface with troilite, the correlation of Ir with Pd implies that most kamacite was not melted because Ir and Pd which have similar diffusive behavior (Righter et al. 2005) have opposite solid/liquid partitioning behavior in metal systems with low concentrations of $\mathrm{P}, \mathrm{S}$, and C (Kelly and Larimer 1977; Campbell and Humayun 2005; Chabot et al. 2006; Walker et al. 2008).

In summary, some perryite at the interface of kamacite and troilite appears to have re-crystallized from melt near the $\mathrm{Fe}-\mathrm{FeS}$ eutectic temperature which may have been depressed by the presence of $\mathrm{Si}$ and other sulfides (Fogel et al. 1989). This hypothesis is consistent with metal-sulfide nodules as preaccretionary objects experiencing short nebular heating events similar to silicate chondrules as proposed by Rambaldi et al. (1986) for Qingzhen.

\section{CONCLUSIONS}

We consider the hypotheses that kamacite, schreibersite, and perryite in Sahara 97072 metalsulfide nodules formed by decomposition of a precursor $\mathrm{Fe}-\mathrm{Ni}$ alloy, by condensation as separate minerals, that perryite formed by sulfidation of Si-rich $\mathrm{Fe}-\mathrm{Ni}$ alloy and from Si-rich melt in transient heating events. The trace element signature of the kamaciteperryite-schreibersite assemblage is consistent with their origin from nebular gas with solar proportions of siderophile elements. Communication of $\mathrm{Fe}-\mathrm{Ni}$ alloy with this gas continued down to temperatures where substantial fractions of $\mathrm{Cu}$ and $\mathrm{Ga}$ condensed. We propose that schreibersite and perryite formed separately near the condensation temperatures of $\mathrm{P}$ and $\mathrm{Si}$ in the reduced gas and were incorporated into $\mathrm{Fe}-\mathrm{Ni}$ alloy. At cooler temperatures, preferential sulfidation of $\mathrm{Fe}$ in kamacite contributed to formation of additional perryite that was subsequently processed by brief melting of the metal-sulfide nodules. The metal-sulfide nodules are pre-accretionary objects that retain a record of their origin in nebular gas overprinted by transient heating events.

Acknowledgments - We thank Lawrence Garvie (Center for Meteorite Studies) for the meteorite sample and expert advice with the scanning electron microscope. We thank Jack Larimer for helpful discussions of these results and for reviewing an early draft of the manuscript and Meenakshi Wadhwa (Center for Meteorite Studies) for reading this transcript and educating SL in meteoritics. This manuscript also benefited from the thoughtful reviews of Ahmed El Goresy, Michael Weisberg, and Munir Humayun. We especially thank Munir Humayun for supplying the mass balance equations. This work was funded by NASA Cosmochemistry grant NNG06GF08G.

\section{Editorial Handling-Dr. Nancy Chabot}

\section{REFERENCES}

Achterbergh E. V., Ryan C. G., Jackson S. E., and Griffin W. L. 2001. Appendix 3: Data reduction software for LAICP-MS. In Laser ablation-ICP-MS in the earth sciences edited by Sylvester P., vol. 29, Short Course Series. Québec: Mineralogical Association of Canada. pp. 243.

Ackerbauer S., Krendelsberger N., Weitzer F., Hiebl K., and Schuster J. C. 2009. The constitution of the ternary system Fe-Ni-Si. Intermetallics 17:414-420.

Campbell A. J. and Humayun M. 2004. Formation of metal in the CH chondrites ALH 85085 and PCA 91467. Geochimica et Cosmochimica Acta 68:3409-3422.

Campbell A. J. and Humayun M. 2005. Compositions of group IVB iron meteorites and their parent melt. Geochimica et Cosmochimica Acta 69:4733-4744.

Campbell A. J., Humayun M., Meibom A., Krot A. N., and Keil K. 2001. Origin of zoned metal grains in the QUE 94411 chondrite. Geochimica et Cosmochimica Acta 65:163-180.

Campbell A. J., Simon S. B., Humayun M., and Grossman L. 2003. Chemical evolution of metal in refractory inclusions in CV3 chondrites. Geochimica et Cosmochimica Acta 67:3119-3134.

Campbell A. J., Humayun M., and Weisberg M. K. 2005a. Compositions of zoned and unzoned metal in the $\mathrm{CB}_{\mathrm{b}}$ chondrites Hammadah al Hamra 237 and Queen Alexandra Range 94627. Meteoritics \& Planetary Science 40:1131-1148.

Campbell A. J., Zanda B., Perron C., Meibom A., and Petaev M. I. 2005b Origin and thermal history of Fe-Ni metal in primitive chondrites. In Chondrites and the protoplanetary disk, edited by Krot A. N., Scott E. R. D., and Reipurth B. vol. 344. San Francisco: Astronomical Society of the Pacific. pp. 407-431.

Chabot N. L. and Jones J. H. 2003. The parameterization of solid metal-liquid metal partitioning of siderophile elements. Meteoritics \& Planetary Science 38:1425-1436. 
Chabot N. L., Campbell A. J., Jones J. H., Humayun M., and Lauer H. V. Jr. 2006. The influence of carbon on trace element partitioning behavior. Geochimica et Cosmochimica Acta 70:1322-1335.

Corrigan C. M., Chabot N. L., McCoy T. J., McDonough W. F., Watson H. C., Saslow S. A., and Ash R. D. 2009. The iron-nickel-phosphorus system: Effects on the distribution of trace elements during the evolution of iron meteorites. Geochimica et Cosmochimica Acta 73:2674-2691.

Dambaev V. A. and Ulyanov A. A. 1998 Opaque minerals in enstatite chondrites: Perryite-silicophosphide $\mathrm{Ni}$ and $\mathrm{Fe}$ in PCA 91085 and conditions of its formation (abstract). 29th Lunar and Planetary Science Conference. p. 1282.

Easton A. J. 1986. Studies of kamacite, perryite, and schreibersite in E-chondrites and aubrites. Meteoritics 21:79-93.

Ehlers K. and El Goresy A. 1988. Normal and reverse zoning in niningerite: A novel key parameter to the thermal histories of EH-chondrites. Geochimica et Cosmochimica Acta 52:877-887.

El Goresy A. 1985. The Qingzhen reaction: Fingerprints of the EH planet? Meteoritics 20:639.

El Goresy A., Yabuki H., Ehlers K., Woolum D. S., and Pernika E. 1988. Qingzhen and Yamato 691: A tentative alphabet soup for the EH chondrites. Proceedings of the NIPR Symposium on Antarctic Meteorites 1:65-101.

Fogel R. A., Hess P. C., and Rutherford M. J. 1989. Intensive parameters of enstatite chondrite metamorphism. Geochimica et Cosmochimica Acta 53:2735-2746.

Grossman L. 1972. Condensation in the primitive solar nebula. Geochimica et Cosmochimica Acta 36:597-619.

Grossman J. N. 1998. The Meteoritical Bulletin, No. 82. Meteoritics \& Planetary Science 33:221-239.

Grossman J. N. and Wasson J. T. 1985. The origin and history of the metal and sulfide components of chondrules. Geochimica et Cosmochimica Acta 49:925-939.

Grossman L., Beckett J. R., Fedkin A. V., Simon S. B., and Ciesla F. J. 2008. Redox conditions in the solar nebula: Observational, experimental, and theoretical constraints. In Oxygen in the solar system, edited by MacPherson G. J. Reviews in Mineralogy and Geochemistry, vol. 68. pp. 93-140.

Hamester M., Weiderin D., Wills J., Kerl W., and Douthitt C. B. 1999. Strategies for isotope ratio measurements with a double focusing sector p eld ICP-MS. Fresenius Journal of Analytical Chemistry 364:495-497.

Horan M. F., Walker R. J., Morgan J. W., Grossman J. N., and Rubin A. E. 2003. Highly siderophile elements in chondrites. Chemical Geology 196:5-20.

Hutson M. and Ruzicka A. 2000. A multi-step model for the origin of E3 (enstatite) chondrites. Meteoritics \& Planetary Science 35:601-608.

Ikeda Y. 1989. Petrochemical study of the Yamato-691 enstatite chondrite (E3) IV: Descriptions and mineral chemistry of opaque-mineral nodules. Proceedings of the NIPR Symposium on Antarctic Meteorites 2:109-146.

Kallemeyn G. W. and Wasson J. T. 1986. Compositions of enstatite (EH3, EH4,5 and EL6) chondrites: implications regarding their formation. Geochimica et Cosmochimica Acta 50:2153-2164.

Kelly W. R. and Larimer J. W. 1977. Chemical fractionations in meteorites-VIII. Iron meteorites and the cosmochemical history of the metal phase. Geochimica et Cosmochimica Acta 41:93-111.
Kimura M. 1988. Origin of opaque minerals in an unequilibrated enstatite chondrite, Yamato-691. Proceedings of the NIPR Symposium on Antarctic Meteorites 1:51-64.

Kong P., Mori T., and Ebihara M. 1997. Compositional continuity of enstatite chondrites and implications for heterogeneous accretion of the enstatite chondrite parent body. Geochimica et Cosmochimica Acta 61:4895-4914.

Kullerud G. and Yoder H. S. 1959. Pyrite stability relations in the FeS-S system. Economic Geology 54:533-572.

Larimer J. W. and Ganapathy R. 1987. The trace element chemistry of $\mathrm{CaS}$ in enstatite chondrites and some implications regarding its origin. Earth and Planetary Science Letters 84:123-134.

Larimer J. W. and Wasson J. T. 1988. Siderophile element fractionation. In Meteorites and the early solar system edited by Kerridge J. F., and Mathews M. S. Tucson, AZ: The University of Arizona Press. pp. 416-435.

Lauretta D. S., Lodders K., and Fegley B. Jr 1997. Experimental simulations of sulfide formation in the solar nebula. Science 277:358-360.

Lin Y. and El Goresy A. 2002. A comparative study of opaque phases in Qingzhen (EH3) and MacAlpine Hills (EL3): Representatives of EH and EL parent bodies. Meteoritics \& Planetary Science 37:577-599.

Lodders K. 2003. Solar system abundances and condensation temperatures of the elements. The Astrophysical Journal 591:1220-1247.

McCoy T., Dickinson T. L., and Lofgren G. E. 1999. Partial melting of the Indarch (EH4) meteorite: A textural, chemical, and phase relations view of melting and melt migration. Meteoritics \& Planetary Science 34:735-746.

McKinley S. G., Scott E. R. D., and Keil K. 1984. Composition and origin of enstatite in $\mathrm{E}$ chondrites. Proceedings, 14th Lunar and Planetary Science Conference, Part 2. Journal of Geophysical Research 89:B567-B572.

Okada A., Kobayashi K., Ito T., and Sakurai T. 1991. Structure of synthetic perryite, $(\mathrm{Ni}, \mathrm{Fe})_{8}(\mathrm{~S}, \mathrm{P})_{3}$. Acta Crystallographica 47:1358-1361.

Petaev M. I. and Wood J. A. 1998. The condensation with partial isolation (CWPI) model of condensation in the solar nebula. Meteoritics \& Planetary Science 33:11231137.

Petaev M. I. and Wood J. A. 2000. The condensation origin of zoned metal grains in Bencubbin/ $\mathrm{CH}$-like chondrites: Thermodynamic model (abstract \#1608). 31st Lunar and Planetary Science Conference. CD-ROM.

Raghavan V. 1988a. Phase diagrams of ternary iron alloys, Part 2. Ternary systems containing iron and sulfur. Calcutta: Indian Institute of Metals. 360 p.

Raghavan V. 1988b. Phase diagrams of ternary iron alloys, Part 3. Ternary systems containing iron and phosphorus. Calcutta: Indian Institute of Metals. 229 p.

Rambaldi E. R., Rajan R. S., Housley R. M., and Wang D. 1986. Gallium-bearing sphalerite in a metal sulfide nodule of the Qingzhen (EH3) chondrite. Meteoritics 21:23-31.

Righter K., Campbell A. J., and Humayun M. 2005. Diffusion of trace elements in FeNi metal: Application to zoned metal grains in chondrites. Geochimica et Cosmochimica Acta 69:3145-3158.

Romig A. D. and Goldstein J. I. 1980. Determination of the $\mathrm{Fe}-\mathrm{Ni}$ and $\mathrm{Fe}-\mathrm{Ni}-\mathrm{P}$ phase diagrams at low temperatures 
(700-300 degrees C). Metallurgical and Materials Transactions A 11:1151-1159.

Rubin A. E. 1985. Impact melt products of chondritic material. Reviews of Geophysics 23.

Scott E. R. D. 1982. Origin of rapidly solidified metal-troilite grains in chondrites and iron meteorites. Geochimica et Cosmochimica Acta 46:813-823.

Sears D. W. 1978. Condensation and the composition of iron meteorites. Earth and Planetary Science Letters 41:128-138.

Skinner B. J. and Luce F. D. 1971. Solid solutions of the type ( $\mathrm{Ca}, \mathrm{Mg}, \mathrm{Mn}, \mathrm{Fe}) \mathrm{S}$ and their use as geothermometers for the enstatite chondrites. American Mineralogist 56:12691296.

Smith B. A. and Goldstein J. I. 1977. The metallic microstructures and thermal histories of severely reheated chondrites. Geochimica et Cosmochimica Acta 41:10611065, 1067-1072.

Waldner P. and Pelton A. 2004. Critical thermodynamic assessment and modeling of the Fe-Ni-S system. Metallurgical and Materials Transactions B 35:897-907.
Walker R. J., McDonough W. F., Honesto J., Chabot N. L., McCoy T. J., Ash R. D., and Bellucci J. J. 2008. Modeling fractional crystallization of group IVB iron meteorites. Geochimica et Cosmochimica Acta 72:2198-2216.

Wasson J. T. and Kallemeyn G. W. 1988. Compositions of chondrites. Philosophical Transactions of the Royal Society of London. 325:535-544.

Weisberg M. K. and Prinz M. 1998 Sahara 97096: A highly primitive EH3 chondrite with layered sulfide-metal-rich chondrules (abstract \#1741). 29th Lunar and Planetary Science Conference. CD-ROM.

Weisberg M. K., Connolly H. C., Ebel D. S., and Kimura M. 2006. Sulfide-metal nodules in EH3 chondrites (abstract). Meteoritics \& Planetary Science 41:A186.

Zanda B., Bourot-Denise M., Perron C., and Hewins R. H. 1994. Origin and metamorphic redistribution of silicon, chromium, and phosphorus in the metal of chondrites. Science 265:1846-1849. 